\title{
Use of sodium chloride and zeolite during shipment of Ancistrus triradiatus under high temperature
}

\author{
Wilson F. Ramírez-Duarte ${ }^{1}$, Carolina Pineda-Quiroga ${ }^{1}$, Nhora Martínez ${ }^{2}$ and \\ Pedro R. Eslava-Mocha ${ }^{1}$
}

The use of sodium chloride $(0.5 \mathrm{~g} / \mathrm{L}$ and $1 \mathrm{~g} / \mathrm{L})$ and zeolite $(22.7 \mathrm{~g} / \mathrm{L})$ during shipment $(48 \mathrm{~h})$ of Ancistrus triradiatus at high temperatures (between 24.5 and $34^{\circ} \mathrm{C}$ ) were evaluated. Several water quality parameters (dissolved oxygen, $\mathrm{pH}$, conductivity, and total ammonia) were measured before and after shipment. Glycemia was measured before shipment and at 24 and $48 \mathrm{~h}$ after shipment. After shipment, a resistance test was carried out in a high concentration of sodium chloride, and mortality was recorded after shipment, and 7 days post-shipment. While the two evaluated substances increased survival of $A$. triradiatus challenged by high temperatures during shipment, the best result was obtained with $1 \mathrm{~g} / \mathrm{L}$ of sodium chloride.

O uso de cloreto de sódio $(0,5 \mathrm{~g} / \mathrm{L}$ e $1 \mathrm{~g} / \mathrm{L})$ e zeolita $(22,7 \mathrm{~g} / \mathrm{L})$ foram avaliados durante o transporte $(48 \mathrm{~h})$ de Ancistrus triradiatus em altas temperaturas (entre 24,5 e $34^{\circ} \mathrm{C}$ ). Os seguintes parâmetros foram monitorados: $\mathrm{pH}$, oxigênio dissolvido, condutividade e amônia antes e depois do transporte. Também foi mensurada a concentração de glicose no sangue antes do transporte e 0,24 e $48 \mathrm{~h}$ após o transporte. Foi realizado um teste de resistência a altas concentrações de cloreto de sódio após o transporte, sendo registrada a mortalidade no final do transporte e após 7 dias. As duas substâncias testadas aumentam a sobrevivência de $A$. triradiatus a altas temperaturas durante o transporte, porém o melhor resultado foi obtido com o uso de $1 \mathrm{~g} / \mathrm{L}$ cloreto de sódio.

Key words: Armored catfish, Clinoptilolite, Fish shipment, Loricariidae, $\mathrm{NaCl}$.

\section{Introduction}

Ancistrus triradiatus or xenocara is an ornamental armored catfish native to the Orinoco basin belonging to the family Loricariidae, the second largest family of ornamental species of commercial interest in Colombia. This family contributed with 4,497,338 units exported in 2009, representing $20.41 \%$ of the total (MADR \& CCI, 2010).

In aquaculture, common management practices, such as handling and shipment of fish, act as stressors associated with physiological deterioration and death of the fish. Shipment is a traumatic procedure that results in negative repercussions due to the initial capture, sorting, packing, container loading, unloading, and storage in a new environment (Carneiro et al., 2007). The mortality associated with shipment is a result of a combination of factors, among which are the accumulation of metabolites, such as ammonia, and nitrites, $\mathrm{pH}$ reduction due to carbon dioxide accumulation, depletion of dissolved oxygen, sudden temperature changes, stress, and infections acquired during shipment (Singh et al., 2004).

In Colombia, the ornamental fish business is centered in the collection of freshwater species, and despite the high amount exported, is threatened by the lack of adequate practices during fish capturing and shipment to ensure fish survival at their final destination. In a characterization of the conditions of artisanal fish capturing and shipment of the ornamental fish of the family Loricariidae in the state of Meta, Colombia, Ramírez-Duarte et al. (2009) reported wide variations in temperature, up to $9.8^{\circ} \mathrm{C}$ within periods of 10 hours, and extreme temperatures of up to $33.4^{\circ} \mathrm{C}$, among other factors, such as low dissolved oxygen concentrations, accumulation of nitrogen compounds, and wide $\mathrm{pH}$ variations.

In order to minimize the adverse effects associated with fish shipment, a variety of techniques have been developed to be applied during their shipment, such as reducing the

${ }^{1}$ Universidad de los Llanos, Grupo de investigación en Sanidad de Organismos Acuáticos, Instituto de Acuicultura de los Llanos. 500017 Villavicencio, Meta, Colombia.wramirezduarte@gmail.com; carolinapineda94@yahoo.es; padre.eslava@gmail.com

${ }^{2}$ Universidad Nacional de Colombia, Departamento de Ciencias para la Producción Animal, Facultad de Medicina Veterinaria y de Zootecnia, 111321 Bogotá DC, Colombia.nmartinezr@bt.unal.edu.co 
water temperature (Lim et al., 2003; Golombieski et al., 2003), use of anesthetics (Iversen et al., 2009; Hasan \& Bart, 2007), zeolite, buffer substances (Singh et al., 2004), probiotics (Gomes et al., 2009), and salt (Carneiro \& Urbinati, 2001), among others.

The addition of sodium chloride in the transport water has been implemented mainly in order to contribute to the electrolyte balance of the fish, reducing the osmotic gradient between the internal fluids and the environmental water (Carneiro et al., 2007). However, all freshwater teleost species do not respond equally to the same concentrations, and salt can even be harmful for some species. In this regard, the benefits of using this substance was demonstrated in tambaqui (Colossoma macropomum) (Gomes et al., 2003), matrinxã (Brycon amazonicus) (Carneiro \& Urbinati, 2001), among others, while in other species, such as in pirarucu (Arapaima gigas) (Gomes et al., 2006) and silver catfish (Rhamdia quelen) (Gomes et al., 1999), the use of salt induces osmoregulatory disturbances and can lead to high mortality during shipment.

Zeolite has been used to remove ammonia from the water in fish production systems, tanks or transport bags (Silapajarn et al., 2006). This substance adsorbs ammonium, exchanging sodium for ammonium, and prevents the increase of ammonia levels. The addition of zeolite improved water quality in the transport of catla (Catla catla), roho labeo (Labeo rohita), mrigal carp (Cirrhinus mrigala) (Kaiser et al., 2006; Singh et al., 2004), the Lake Victoria cichlid (Haplochromis obliquidens) (Kaiser et al., 2006), and guppy (Poecilia reticulata) (Teo et al., 1989).

The aim of this study was to evaluate the effect of the inclusion of sodium chloride and zeolite on the survival of $A$. triradiatus subjected to shipping under high temperatures.

\section{Material and Methods}

Wild specimens of $A$. triradiatus, with marketable size $(\mathrm{n}=324 ; 10.4 \pm 4.6 \mathrm{~g})$ and acquired through local distributors, were used. Fish were acclimated for at least 15 days in a concrete pool of $3 \mathrm{~m}^{3}$. Mortality during acclimation was $0.89 \%$. Fish were fed once daily with commercial feed with $30 \%$ crude protein. The food given to the fish was discontinued 3 days prior to the beginning of the transport period. Voucher specimens were deposited in the fish collection of Instituto de Ciencias Naturales of Universidad Nacional de Colombia (ICN Number 17649).

The inclusion of sodium chloride $(0.5$ and $1 \mathrm{~g} / \mathrm{L})$ and zeolite $(22.7 \mathrm{~g} / \mathrm{L})$ in the transport water was evaluated separately. The concentrations of sodium chloride and zeolite (clinoptilolite, ProLine ${ }^{\circledR}$ Aquatic Eco-Systems, Inc.) were established based on preliminary experiments. For the latter, the inclusion rate recommended by the manufacturer also was taken into account, which was $1 \mathrm{~g}$ of zeolite per 1.5 $\mathrm{mg}$ total ammonia. There was also a control group not exposed to any of the experimental substances. The experiment was run in triplicate.
Fish were weighed (balance Traveler ${ }^{\mathrm{TM}}$ TA3001, OHAUS) and packed in double plastic bags (type $\mathrm{B}$ for export) with $4 \mathrm{~L}$ of water from a deep well, maintaining a ratio by volume of 3 parts of pure oxygen to 1 part of water, and sealed with rubber bands. Each bag received 27 fish, representing a biomass of $61.75 \mathrm{~g} / \mathrm{L}$. The bags were packed in cardboard boxes and transported in the baggage compartment of a bus where it was dark. No measures were taken to regulate the temperature, allowing it to vary with the temperature of the baggage compartment. The experimental period of shipment took $48 \mathrm{~h}$.

Just prior to packing the fish in the plastic transport bags, and at the end of each of the experiments, water temperature, dissolved oxygen (oximeter Oxi 330i, WTW, Germany), pH, conductivity (multiparameter HI 98129, HANNA Instruments, USA), total ammonia concentration (spectrophotometry with a colorimetric kit Spectroquant, Merck $^{\circledR}$ - SPECTRONIC ${ }^{\circledR} 20$ GENESYS, Spectronic Instruments), hardness (EDTA titrimetric method), and alkalinity (by titration with bromocresol green) (APHA, 1998) were measured. Additionally, non-ionized ammonia levels were calculated using the formulas of Bower \& Bidwell (1978), and Johansson $\&$ Wedborg (1980). During the experimental period temperature was recorded with a maximum and minimum thermometer (SPER SCIENTIFIC), for which two thermometers were included in two bags packed in the same conditions as the fish, and kept in the boxes with the bags that contained the fish.

The water quality parameters at the beginning of the experiments were: over-saturation of dissolved oxygen, $\mathrm{pH}$ $7.29 \pm 0.02$, total ammonia $0.06 \pm 0 \mathrm{mg} / \mathrm{L}$, hardness $9.13 \pm 3.80$ $\mathrm{mg} / \mathrm{L}$, total alkalinity $4.87 \pm 0.50 \mathrm{mg} / \mathrm{L}$, conductivity of $90.3 \pm$ $0.6 \mu \mathrm{S} / \mathrm{cm}$ in the control, of $1008.7 \pm 0.6 \mu \mathrm{S} / \mathrm{cm}$ in salt $0.5 \mathrm{~g} / \mathrm{L}$, $2001 \pm 5.2 \mu \mathrm{S} / \mathrm{cm}$ in salt $1 \mathrm{~g} / \mathrm{L}$, and $88.7 \pm 0.6 \mu \mathrm{S} / \mathrm{cm}$ in the group exposed to zeolite.

At the end of the experimental period, a resistance test to conditions of hyperosmolarity was performed by the immersion of 20 fish of each treatment ( 7 fish of 2 replicates and 6 fish of the remaining) in water with $2 \%$ salt $(\mathrm{NaCl}$, free of iodine and fluorine), and the number of fish that retained the swimming axis during 1 hour at 5 minute intervals was recorded. Once a fish lost the swimming axis, it was removed and left to recover in a salt-free aquarium.

Blood glucose levels were also measured at the end of shipment (time $0 \mathrm{~h})(\mathrm{n}=6$ for each treatment). The remaining fish were placed in a concrete pool (separated by replicate per each treatment), and their blood glucose concentration was measured at $24 \mathrm{~h}$ and $48 \mathrm{~h}$ after shipment. The blood glucose of 10 fish was also determined during the acclimation period prior to shipment. This measurement was taken as the basal concentration pre-shipment. The blood glucose concentration was determined with a glucose meter AccuChek $^{\circledR}$ Active (Roche). For blood sampling, the fish were anesthetized with eugenol $(150 \mathrm{mg} / \mathrm{L})$ for 5 minutes. Fish that were not used in the tests described above were kept in a concrete pool (separated by replicate per each treatment), and cumulative mortality was recorded 7 days after shipment. 


\section{Statistical analysis}

Homogeneity of variances was determined with the Levene test $(p<0.05)$ for water parameters and blood glucose data. Significant differences between groups were established with the ANOVA test, followed by a Tukey-Kramer test of multiple comparisons.

Mortality results were analyzed by frequency distribution; the Chi square test of independence was used to establish significant differences between groups, and also within each group, as well as between mortality at the end of shipment, and 7 days after shipment for the same group.

The results of the resistance test to stress were analyzed using a multiple regression test, utilizing a linear model with a qualitative predictor for the group, which has $\mathrm{n}$ classes corresponding to the number of groups (Kutner et al., 2005).

In all cases the SAS software, version 8.05 was used and significant differences were established with $\mathrm{p}<0.05$.

\section{Results}

Dissolved oxygen was preserved at oversaturation conditions. In all groups, there was a drop in $\mathrm{pH}$, which was significantly lower $(\mathrm{p}<0.05)$ in the groups exposed to salt. Conductivity increased in all groups at the end of shipment, but the variation was significantly lower in the groups exposed to salt. Total ammonia concentration was highest in the control group, and lowest in the group exposed to zeolite. A similar situation was found with non-ionized ammonia (Table 1). Water temperature varied between 28 and $34^{\circ} \mathrm{C}$ during the day, and between 24.5 and $26^{\circ} \mathrm{C}$ at night.

\section{Blood glucose concentration}

The control group and the group exposed to zeolite showed a significant increase $(p<0.05)$ of blood glucose level at the end of shipment $(0 \mathrm{~h})$ comparing to the pre-shipment baseline level, returning to the baseline level $24 \mathrm{~h}$ later. The groups exposed to salt showed no significant variations in basal blood glucose level immediately after shipment, and in the subsequent times post-shipment blood glucose levels were significantly lower $(p<0.05)$ than the control and the

Table 1. Water parameters at the end of transport (48h) of Ancistrus triradiatus in plastic bags. ${ }^{*} \triangle$ Conductivity represents the increase in conductivity between the beginning and end of transport. Data are expressed as mean \pm standard deviation. Different letters indicate significant differences between groups.

\begin{tabular}{lcccc}
\hline Group & $\mathrm{pH}$ & $\begin{array}{c}\Delta \text { Conductivity* } \\
(\mu \mathrm{S} / \mathrm{cm})\end{array}$ & $\begin{array}{c}\text { Total } \\
\text { ammonia } \\
(\mathrm{mg} / \mathrm{L})\end{array}$ & $\begin{array}{c}\text { Non-ionized } \\
\text { Ammonia } \\
(\mathrm{mg} / \mathrm{L})\end{array}$ \\
\hline Control & $6.36 \pm 0.14^{\mathrm{a}}$ & $1727.3 \pm 1033.9^{\mathrm{a}}$ & $51.6 \pm 2.3^{\mathrm{a}}$ & $0.0185 \pm 0.0017^{\mathrm{a}}$ \\
Salt $0.5 \mathrm{~g} / \mathrm{L}$ & $5.92 \pm 0.16^{\mathrm{b}}$ & $303.3 \pm 111.5^{\mathrm{b}}$ & $33.8 \pm 1.8^{\mathrm{b}}$ & $0.0065 \pm 0.0023^{\mathrm{b}}$ \\
Salt 1 g/L & $5.81 \pm 0.05^{\mathrm{b}}$ & $167.0 \pm 13.5^{\mathrm{b}}$ & $32.2 \pm 2.1^{\mathrm{b}}$ & $0.0046 \pm 0.0005^{\mathrm{b}}$ \\
Zeolite & $6.30 \pm 0.09^{\mathrm{a}}$ & $626.7 \pm 248.7^{\mathrm{a}, \mathrm{b}}$ & $15.5 \pm 4.1^{\mathrm{c}}$ & $0.0068 \pm 0.0022^{\mathrm{b}}$ \\
\hline
\end{tabular}

group exposed to zeolite at the time $0 \mathrm{~h}$ (Table 2). For the control group, there was no blood glucose concentrations recorded in 24 hours and 48 hours post-shipment due to the high mortality presented.

\section{Mortality}

Mortality at day 0 post-shipment and the accumulated mortality up to day 7 were significantly lower $(p<0.05)$ in both groups exposed to salt, being that the control group had the highest mortality (Table 3 ). After 7 days postshipment, only the zeolite group showed a significant increase in mortality with respect to that found on day 0 post-shipment. Due the high mortality registered in the control group at the end of transport, there were not enough fish to evaluate the accumulative mortality at 7 days post-shipment, so the same data is recorded on days 0 and 7 .

\section{Resistance test to conditions of hyperosmolarity}

The linear regression model between the number of fish that maintained the swimming axis (y), and time of exposure to hyperosmotic saline solution, shows an inverse relationship $(\mathrm{p}<0.0001)$, where the zeolite group showed significant differences $(\mathrm{p}<0.05)$ compared to other groups, indicating less resistance to conditions of hyperosmolarity (Fig. 1). There were no significant differences between the other groups $(\mathrm{p}<0.05)$. The relationships can be expressed by the following equations:

$$
\begin{aligned}
& \text { Control, } \mathrm{y}=17.02524+(-0.42819 \times \text { Time }) \\
& \text { Salt } 0.5 \mathrm{~g} / \mathrm{L}, \mathrm{y}=17.56381+(-0.42819 \times \text { Time }) \\
& \text { Salt } 1 \mathrm{~g} / \mathrm{L}, \mathrm{y}=18.11834+(-0.42819 \times \text { Time }) \\
& \text { Zeolite, } \mathrm{y}=12.01904+(-0.42819 \times \text { Time })
\end{aligned}
$$

\section{Discussion}

It has been reported that freshwater tropical fishes live in a temperature range between 20 and $30^{\circ} \mathrm{C}$ (Almeida-Val et al., 2005). Exposure to wide temperature variations over short periods of time, or to temperatures outside the range of comfort, as reported in conditions of shipment of ornamental

Table 2. Blood glucose levels in Ancistrus triradiatus before and after transport in plastic bags. $\mathrm{N}=10$. $\uparrow$ Data not taken because of the insufficient number of animals. Data are expressed as mean \pm standard deviation. * indicate significant difference from before transport. Different capital letters indicate significant difference between groups in the same sampling time.

\begin{tabular}{lcccc}
\hline \multicolumn{5}{c}{ Blood glucose levels $(\mathrm{mg} / \mathrm{dL})$} \\
Group & Before transport & $0 \mathrm{~h}$ & $24 \mathrm{~h}$ & $48 \mathrm{~h}$ \\
\hline Control & $16.7 \pm 4.3$ & $63.6 \pm 11.8^{* \mathrm{~A}}$ & $\dagger$ & $\dagger$ \\
Salt $0.5 \mathrm{~g} / \mathrm{L}$ & & $21.0 \pm 6.6^{\mathrm{B}}$ & $28.0 \pm 11.6^{\mathrm{B}}$ & $17.3 \pm 4.6^{\mathrm{B}}$ \\
Salt $1 \mathrm{~g} / \mathrm{L}$ & & $26.5 \pm 7.8^{\mathrm{B}}$ & $21.0 \pm 5.3^{\mathrm{B}}$ & $25.6 \pm 3.7^{\mathrm{B}}$ \\
Zeolite & & $63.0 \pm 28.2^{* \mathrm{~A}}$ & $21.8 \pm 10.3^{\mathrm{B}}$ & $29.3 \pm 8.2^{\mathrm{B}}$ \\
\hline
\end{tabular}


Table 3. Mortality at the end of shipment of Ancistrus triradiatus in plastic bags and 7 days after transport. Different lowercase letters indicate significant difference between groups in the same day. Different capital letters indicate significant difference between days 0 and 7 for the same group.

\begin{tabular}{lcc}
\hline & \multicolumn{2}{c}{ Mortality (\%) } \\
Group & Day 0 & Accumulated up to day 7 \\
\hline Control & $71.1^{\mathrm{a}}$ & $71.1^{\mathrm{a}}$ \\
Salt $0.5 \mathrm{~g} / \mathrm{L}$ & $3.1^{\mathrm{b}}$ & $6.3^{\mathrm{b}}$ \\
Salt $1 \mathrm{~g} / \mathrm{L}$ & $0^{\mathrm{b}}$ & $2.0^{\mathrm{b}}$ \\
Zeolite & $27.8^{\mathrm{c}, \mathrm{A}}$ & $41.2^{\mathrm{c}, \mathrm{B}}$ \\
\hline
\end{tabular}

fish in Colombia by Ramírez-Duarte et al. (2009), and as evaluated in this study, increases the metabolic rate of fish, and reduces the reserves of lipids, plasma protein concentrations, blood osmolality and serum electrolyte concentrations, all conditions that can lead to the death of individuals or increase their susceptibility to diseases (Wendelaar Bonga, 1997; Portz et al., 2006).

The significant increase of the conductivity and ammonia levels in the control group at the end of shipment may be mainly due to the mortality observed. However, it is presumed that, in addition to mortality, electrolyte imbalance resulting from increased branchial permeability (Wendelaar Bonga, 1997), contributed to the results in the control group. Although the group exposed to zeolite also showed a statistically higher mortality rate to that found in the groups exposed to salt, it showed total ammonia levels statistically lower $(p<0.05)$ than the other groups, which resulted from the adsorption of ammonia by zeolite (Singh et al., 2004; Wen et al., 2006). The lower mortality ammonia levels in the zeolite group compared with the control group may reflect the deleterious effect of total ammonia levels reached in the control group. While nonionized ammonia levels found in this study (Table 1) are below the range of $\mathrm{LC}_{50}$ values at $96 \mathrm{~h}$ reported for teleosts $(\geq 0.44$ $\mathrm{mg} / \mathrm{L}$ ) for $\mathrm{pH}$ values between 6 and 8.2 (Rodrigues et al., 2007; Miron et al., 2008), and there are no known data on sensitivity of $A$. triradiatus to total ammonia or to its nonionized form, total ammonia concentrations found in this study are higher than the total ammonia $\mathrm{LC}_{50}$ at $96 \mathrm{~h}$ as described for other teleosts $(\geq 12.7 \mathrm{mg} / \mathrm{L}$ ) (Tomasso \& Carmichael, 1986; Wicks et al., 2002), so the concentrations found in this study $(>15 \mathrm{mg} / \mathrm{L}$, Table 1) may have exerted adverse effects on the fish being studied. Sublethal alterations have been described in the mrigal (Cirrhinus mrigala) consisting of changes in the hematocrit and buffy coat, reduced hemoglobin and serum proteins, and elevated glucose, alanine aminotransferase, and aspartate aminotransferase in specimens exposed to total ammonia levels between 1 and $16 \mathrm{mg} / \mathrm{L}$, with the $\mathrm{LC}_{50}$ of 11.8 $\mathrm{mg} / \mathrm{L}$ for this species (Das et al., 2004).

The low $\mathrm{pH}$ recorded in the groups exposed to salt (Table 1) is outside the range (approx. 6.5 to 7.5) commonly found in the natural habitats of this species (Ramírez-Duarte et al.,

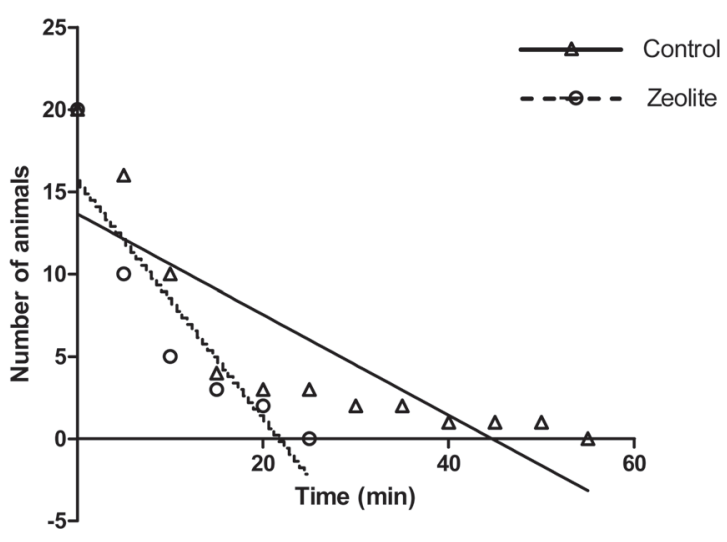

Fig. 1. Linear regression between the number of Ancistrus triradiatus that maintained the swimming axis and time of exposure to hyperosmotic saline solution for control and zeolite groups.

2009), so the use of buffer substances that maintain relatively stable $\mathrm{pH}$ may be indicated (Lim et al., 2003).

The increase in glucose concentration is a characteristic response of fish exposed to acute and chronic stressors (Morales et al., 1990; Pottinger \& Carrick, 1999; Trenzado et al., 2006). Blood glucose levels without significant differences from the recorded pre-shipment baseline level during all stages of sampling in the groups exposed to salt, and significantly lower than that recorded at the end of shipment for the other groups, indicates stress reduction had been achieved with the addition of salt. Adding salt to water reduces the osmotic gradient between plasma and the external environment, reducing thus the loss of electrolytes to the aquatic environment (Carneiro et al., 2007). However, it is possible that salt may have more of a direct effect on the stress response.

Most of the available information on the use of $\mathrm{NaCl}$ in the shipment of fish reported beneficial effects on the survival and stress reduction in freshwater teleost fish at concentrations between 6 and $8 \mathrm{~g} / \mathrm{L}$ for up to $96 \mathrm{~h}$. In goldfish (Carassius auratus), Luz et al. (2008) have reported that salt concentrations between 2 and $6 \mathrm{~g} / \mathrm{L}$ in exposures of 21 days did not induce significant physiological changes, and contributed to reducing the incidence of disease and mortality, but at higher concentrations increases the stress. Carneiro \& Urbinati (2001) reported beneficial effects on stress reduction in matrinxã during a transport of $4 \mathrm{~h}$ at a concentration of $6 \mathrm{~g} / \mathrm{L}$ together with stable $\mathrm{Na}^{+}$and $\mathrm{Cl}^{-}$serum levels, which shows the contribution to the electrolyte balance generated by the addition of salt, as in this present work is reflected in a lower increase of water conductivity. However, it is known that the threshold of resistance to salt concentrations of $A$. triradiatus is low, and the exposure to concentrations equal to or greater than $2 \mathrm{~g} / \mathrm{L}$, in periods of $48 \mathrm{~h}$, induces greater cumulative mortality during the 7 day post-shipment period. 
Exposure to hyperosmolarity conditions has been suggested to evaluate the resistance to stress, where high resistance to stress indicates increased survival of the fish subjected to stressful conditions (Lim et al., 2003). Stress increases branchial water permeability, and leads to changes in plasma electrolyte concentrations in hypo-osmotic or hyperosmotic environments (Carneiro et al., 2007). In the present study, it was established that the zeolite exposed group had a significant reduction in resistance to hyperosmolarity conditions when compared with the other groups. How the exposure to zeolite can reduce osmoregulatory capacity is unknown.

The severity of stress induced by high temperatures can be mitigated or exacerbated by various factors of water quality. In this case, the use of sodium chloride, or zeolite, increased the survival of $A$. triradiatus subjected to high temperatures during the processes of shipping. However, the best result was obtained with the use of $1 \mathrm{~g} / \mathrm{L}$ of sodium chloride.

\section{Acknowledgements}

This study was developed under the project "Construction of the first epidemiological map of ornamental fish diseases in Colombia," contract n ${ }^{\circ}$ 057-2007U4448-387-07, funded by the Ministry of Agriculture and Rural Development of Colombia, national convocation for the joint financing of programs of research, technological development, and innovation for the agricultural sector through productive chains, 2007.

The authors express their gratitude to the transport system of the Universidad de los Llanos, to Victor Kondo for checking the English and the young members of the Research Group of Aquatic Organisms Health of the Universidad de los Llanos, whom collaborated in the development of the experiments.

\section{Literature Cited}

Almeida Val, V. M. F., A. R. Chiparri Gomes \& N. P. Lopes. 2005. Metabolic and physiological adjustments to low oxygen and high temperature in fishes of the Amazon. Pp. 443-500. In: Adalberto, L., V. M. F. D. A. -V. Val \& J. R. David (Eds). Fish Physiology. Academic Press, 634p.

APHA, 1998. Standard Methods for the Examination of Water and Wastewater, $20^{\text {th }}$ edition. Washington, American Public Health Association.

Bower, C. \& J. Bidwell. 1978. Ionization of ammonia in sea water effects of temperature, $\mathrm{pH}$, and salinity on Salmo salar L. Journal of the Fisheries Research Board of Canada, 35: 1012-1016.

Carneiro, P. C. F. \& E. C. Urbinati. 2001. Salt as a stress response mitigator of matrinxã, Brycon cephalus (Gunther), during transport. Aquaculture Research, 32: 297-304.

Carneiro, P. C. F., E. C. Urbinati \& F. Bendhack. 2007. Osmoregulation and fish transport. Pp. 237-248. In: Baldisserotto, J. M. Mancera \& B. G. Kapoor (Eds). Fish Osmoregulation. India, Science Publishers, 527p.

Das, P. C., S. Ayyappan, J. K. Jena \& B. K. Das. 2004. Acute toxicity of ammonia and its sub-lethal effects on selected haematological and enzymatic parameters of mrigal, Cirrhinus mrigala (Hamilton). Aquaculture Research, 35: 134-143.

Golombieski, J. I., L. V. F. Silva, B. Baldisserotto \& J. H. S. da Silva. 2003. Transport of silver catfish (Rhamdia quelen) fingerlings at different times, load densities, and temperatures. Aquaculture, 216: 95-102.

Gomes, L. D. C., C. A. R. M. Araujo-Lima, R. Roubach \& E. C. Urbinati. 2003. Avaliação dos efeitos da adição de sal e da densidade no transporte de tambaqui. Pesquisa Agropecuaria Brasileira, 38: 283-290.

Gomes, L. C., R. P. Brinn, J. L. Marcon, L. A. Dantas, F. R Brandão, J. S. de Abreu, P. E. M. Lemos, D. M. McComb \& B. Baldisserotto. 2009. Benefits of using the probiotic Efinol ${ }^{\circledR} \mathrm{L}$ during transportation of cardinal tetra, Paracheirodon axelrodi (Shultz), in the Amazon. Aquaculture Research, 40: 157-165.

Gomes, L. C., E. C. Chagas, R. P. Brinn, R. Roubach, C. E. Coppati \& B. Baldisserotto. 2006. Use of salt during transportation of air breathing pirarucu juveniles (Arapaima gigas) in plastic bags. Aquaculture, 256: 521-528.

Gomes, L. C., J. I. Golombieski, A. R. Chippari-Gomes \& B. Baldisserotto. 1999. Effect of salt in the water for transport on survival and on $\mathrm{Na}^{+}$and $\mathrm{K}^{+}$body levels of silver catfish, Rhamdia quelen, fingerlings. Journal of Applied Aquaculture, 9: 1-9.

Hasan, M. \& A. N. Bart. 2007. Improved survival of rohu, Labeo rohita (Hamilton-Buchanan) and silver carp, Hypophthalmichthys molitrix (Valenciennes) fingerlings using low-dose quinaldine and benzocaine during transport. Aquaculture Research, 38: 50-58.

Iversen, M., R. A. Eliassen \& B. Finstad. 2009. Potential benefit of clove oil sedation on animal welfare during salmon smolt, Salmo salar L. transport and transfer to sea. Aquaculture Research, 40: 233-241.

Johansson, O. \& M. Wedborg. 1980. The ammonia-ammonium equilibrium in the seawater at temperature between 5 and $25^{\circ} \mathrm{C}$. Journal of Solution Chemistry, 9(1): 37-44.

Kaiser, H., G. Brill, J. Cahill, P. Collett, K. Czypionka, A. Green, K. Orr, P. Pattrick, R. Scheepers, T. Stonier, M. A. Whitehead $\&$ R. Yearsley. 2006. Testing clove oil as an anaesthetic for long-distance transport of live fish: the case of Lake Victoria cichlid Haplochromis obliquidens. Journal of Applied Ichthyology, 22: 510-514.

Kutner, M., C. Nachtsheim, J. Neter \& W. Li. 2005. Applied linear statistical models. Irwin, Boston, McGraw-Hill, 1424p.

Lim, L. C., P. Dhert \& P. Sorgeloos. 2003. Recent developments and improvements in ornamental fish packaging systems for air transport. Aquaculture Research, 34: 923-935.

Luz, R. K., R. M. Martínez-Álvarez, N. de Pedro \& M. J. Delgado. 2008. Growth, food intake regulation and metabolic adaptations in goldfish (Carassius auratus) exposed to different salinities. Aquaculture, 276: 171-178.

Ministerio de Agricultura y Desarrollo Rural \& Corporación Colombiana Internacional. 2010. Pesca y acuicultura Colombia, 46p.

Miron, D. D. S., B. Morales, A. G. Becker, M. Crestani, R. Spanevello, V. L. Loro \& B. Baldisserotto. 2008. Ammonia and $\mathrm{pH}$ effects on some metabolic parameters and gill histology of silver catfish, Rhamdia quelen (Heptapteridae). Aquaculture, 277: 192-196.

Morales, A. E., L. García-Rejón \& M. D. L. Higuera. 1990. Influence of handling and /or anesthesia on stress response in rainbow trout. Effects on liver primary metabolism. Comparative Biochemistry and Physiology Part A: Physiology, 95: 87-93. 
Portz, D., C. Woodley \& J. Cech. 2006. Stress-associated impacts of short term holding on fishes. Reviews in Fish Biology and Fisheries, 16: 125-170.

Pottinger, T. G. \& T. R. Carrick. 1999. A comparison of plasma glucose and plasma cortisol as selection markers for high and low stress-responsiveness in female rainbow trout. Aquaculture, 175: 351-363.

Ramírez-Duarte, W., S. Parada, N. Martínez, P. Eslava-Mocha, J. Figueroa \& C. Iregui. 2009. Manejo de peces de la familia Loricariidae en el municipio de Acacías, Meta: monitoreo desde la captura hasta la comercialización (Reporte preliminar). In: Memorias XV Jornada de Acuicultura, Instituto de Acuicultura, Universidad de los Llanos (Eds), Villavicencio, Meta, (Colombia), 58-65p.

Rodrigues, R. V., M. H. Schwarz., B. C. Delbos \& L. A. Sampaio. 2007. Acute toxicity and sublethal effects of ammonia and nitrite for juvenile cobia Rachycentron canadum. Aquaculture, 271: 553-557.

Silapajarn, O., K. Silapajarn \& C. Boid. 2006. Evaluation of zeolite products used for aquiculture in Thailand. Journal of the World Aquaculture Society, 37: 136-138.

Singh, R., V. Vartak, A. Balange \& M. Ghughuskar. 2004. Water quality management during transportation of fry of Indian major carps, Catla catla (Hamilton), Labeo rohita (Hamilton) and Cirrhinus mrigala (Hamilton). Aquaculture, 235: 297-302.
Teo, L. H., T. W. Chen \& B. H. Lee. 1989. Packaging of the guppy, Poecilia reticulata, for air transport in a closed system. Aquaculture, 78: 321-332.

Tomasso, J. \& G. Carmichael. 1986. Acute toxicity of ammonia, nitrite, and nitrate to the Guadalupe bass, Micropterus treculi. Bulletin of Environmental Contamination and Toxicology, 36: 866-870.

Trenzado, C. E., A. E. Morales \& M. de la Higuera. 2006. Physiological effects of crowding in rainbow trout, Oncorhynchus mykiss, selected for low and stress responsiveness. Aquaculture, 258: 583-593.

Wen, D., Y.-S. Ho \& X. Tang. 2006. Comparative sorption kinetic studies of ammonium onto zeolite. Journal of Hazardous Materials, 133: 252-256.

Wendelaar Bonga, S.E. 1997. The stress response in fish. Physiological Reviews, 77: 591-625.

Wicks, B. J., R. Joensen, Q. Tang \& D. J. Randall. 2002. Swimming and ammonia toxicity in salmonids: the effect to sub lethal ammonia exposure on the swimming performance of coho salmon and the acute toxicity of ammonia in swimming and resting rainbow trout. Aquatic Toxicology, 59: 55-69.

Submitted January 26, 2011

Accepted June 27, 2011

Published December 26, 2011 